\title{
ARTÍCULO ORIGINAL
}

\section{Serological Evidence of Leptospira Infection in Veterinary Students, Bogota, Colombia}

\author{
Iván Méndez ${ }^{1}$, Andrea Rodríguez ${ }^{2}$, Diana Pachón ${ }^{1}$, Luis Cabrera $^{3}$
}

\begin{abstract}
Introduction: Leptospirosis is a zoonotic disease caused by Leptospira interrogans and is transmitted by direct contact with animal secretions or contaminated water. Veterinary and veterinary students are population at risk of infection. Objective: To determine the seroprevalence of Leptospira interrogans infection among students in a School of Veterinary Medicine in Bogotá, Colombia. Methods: We processed 445 sera by ELISA test; then we analyzed 42 samples by microagglutination (MAT). Results: Leptospira seroprevalence by ELISA IgM was $7.9 \%$ (35 of 445). 34 sera were positive by MAT at least for one serovar. Conclusion: This study confirms the usefulness of serological diagnosis in individuals with occupational risk for Leptospirosis and stand out the importance of using protective barriers by all populations who have regular animal contact including veterinary students.
\end{abstract}

Key words: Leptospira, seroepidemiologic studies, agglutination.

\section{Título: Evidencia serológica de infección por Leptospira en estudiantes de medicina veterinaria en Bogotá, Colombia}

\section{Resumen}

Introduccion: La leptospirosis es una enfermedad zoonótica causada por Leptospira interrogans y es transmitida por contacto directo con secreciones animales o agua contaminada. Veterinarios y estudiantes de medicina veterinaria son población en riesgo

1 MSc. School of Medicine, Universidad Militar Nueva Granada, Bogota, Colombia. Member of Microbial Pathogenicity Research Group.

2 Student Internship. School of Medicine, Universidad Militar Nueva Granada, Bogota, Colombia. Member of Microbial Pathogenicity Research Group.

3 Veterinary MD, School of Veterinary Medicine, Universidad de La Salle, Bogota, Colombia. Currently Hermano de La Salle High School.

Received: 01/10/2013 
de adquirir la infección. Objetivo: Determinar la seroprevalencia de infección por Leptospira interrogans entre estudiantes de una facultad de medicina veterinaria en Bogotá, Colombia. Métodos: Se procesaron 445 sueros por ELISA, de los cuales 42 muestras se analizaron mediante microaglutinación (MAT). Resultados: La seroprevalencia a Leptospira por ELISA IgM fue del 7,9 \% (35 de 445). De ellos 34 sueros fueron positivos por MAT al menos para un serovar. Conclusión: Este estudio confirma la utilidad del diagnóstico serológico en individuos con riesgo ocupacional para adquirir la leptospirosis y resalta la importancia del uso de barreras de protección para todas las poblaciones que tienen contacto regular con animales, incluidos los estudiantes de medicina veterinaria.

Palabras clave: Leptospira, estudios seroepidemiológicos, aglutinación.

\section{Introduction}

Leptospirosis is a zoonotic reemerging disease causing a major health problem all over the world. The etiological agent is a gram negative spirochete from the genus Leptospira with many serovars capable of surviving in water [1,2].

Animal reservoirs are rodents, dogs, cattle, pigs, among others. Transmission occurs by direct or indirect contact with secretions or material contaminated with the urine of these reservoirs. The clinical presentation in humans ranges from asymptomatic, mild $(90 \%)$ and severe to Weil syndrome with jaundice and renal failure $(5-10 \%)[1,3]$.

The global estimated annual incidence of this disease is about half a million people. In humans, infection is related with animal contact in occupational activities such as veterinarians, farmers, slaughterhouse, and rural workers $[4,5]$.

We aimed this descriptive and observational study to determine the seroprevalence of Leptospira in students of a School of Veterinary Medicine in Bogota, Colombia.

\section{Methods}

A population of 445 students of veterinary medicine was surveyed according to convenience sampling after signing the written informed consent. In order to assess the sera, we tested each sample by IgM-ELISA test (Panbio $\left.{ }^{\circledR}\right)[3,6]$, and then positive samples were subjected to microagglutination (MAT) on six Leptospira serovars (Hardjo, Pomona, Canicola, Tarassovi, Bratislava, Icterohaemorrahagiae) $[3,7]$.

Data were collected and evaluated in Microsoft Excel $^{\circledR}$ and Statistical Package for Social Sciences $\left(\mathrm{SPSS}^{\circledR}\right)$.

\section{Results}

A total of 455 people enrolled, 224 were men $(50.3 \%)$ and $221(49.7 \%)$ women aged between $16-45$ years and a mean of 21.3 years; $72.6 \%$ from Bogota. Of these, 441 students $(99.1 \%)$ reported contact with animal secretions, 429 (96.4\%) 
with dogs, 355 (79.8\%) with cattle, 312 $(70.1 \%)$ with horses, $78(17.5 \%)$ with rodents and less than $15 \%$ with other species such as pigs, poultry, sheep and goats; $89.4 \%$ of subjects reported contact during their training.

Through an epidemiological survey we collected information about symptoms over the last 3 months before sampling: headache (59.6\%), muscular pain $(30.8 \%)$, fever $(25.1 \%)$, joint pain $(20.4 \%)$, suffusion $(11.3 \%)$, burning during urination (7\%), retroauricular pain (5\%), and jaundice $(3.8 \%)$ we reproted.

Thirty five students (7.7\%) were positive for IgM-ELISA, 42 samples (35 IgM positive, 7 IgM negative) were subjected to MAT agglutination test; seropositivity was obtained in 34 of them at least for one serovar (Table 1).

Table 1. Leptospira Serovars by Microagglutination among Students of Veterinary Medicine (n=34), Bogota, Colombia

\begin{tabular}{|l|c|}
\hline \multicolumn{1}{|c|}{ Serovar } & No. positive (\%) \\
\hline Hardjo & $14(41.2)$ \\
\hline Pomona & $24(70.6)$ \\
\hline Canicola & $16(47.1)$ \\
\hline Tarassovi & $14(41.2)$ \\
\hline Bratislava & $15(44.1)$ \\
\hline Icterohaemorrahagiae & $8(23.5)$ \\
\hline
\end{tabular}

\section{Discussion}

This study confirms the usefulness of serological diagnosis in individuals with occupational risks for Leptospirosis.

According to the last bulletin of Colombian National Institute of Health, during the first semester of 2013, 327 cases of Leptospirosis (33 deceased) had been confirmed, with an incidence of 0.69 per 100,000 inhabitants [8].

As we expected, Canicola, Pomona, and Hardjo were predominant serovars (Table 1 ), because at least $80 \%$ of students had had dog or cattle contact [1].

Four students were positive for all 6 serovars tested, two for 5 serovars and 7 for Pomona serovar (Table 2). These findings are similar to described by Sanchez et al. in 69 MAT-positive patients where 97\% had antibodies to more than two serovars, predominantly Icterohaemorrhagiae and Gryppotyphosa [9].

In a different study, Herrmann-Storck concludes that infection with Leptospira serovar Icterohaemorrhagiae could be a prognostic factor for severe outcomes despite of Susuki and Ariyoshi concerns about that conclusion [10]. In our study, only $23.5 \%$ of students were positive for MAT against that serovar, but in contrast to the study of HerrmannStorck, similar symptoms were displayed by subjects with infection by other serovars. 
Table 2. Co-agglutination by Microagglutination Among 34 Students of a School of Veterinary Medicine, Bogota, Colombia

\begin{tabular}{|c|c|c|c|}
\hline Serovar & $\begin{array}{c}\text { No. of Positive } \\
\text { Individuals }\end{array}$ & Serovar & $\begin{array}{c}\text { No. of Positive } \\
\text { Individuals }\end{array}$ \\
\hline HPCTBI & 4 & CT & 1 \\
\hline HPCTB & 2 & CTB & 1 \\
\hline P & 7 & PT & 1 \\
\hline TBI & 1 & HPTI & 1 \\
\hline B & 2 & HP & 1 \\
\hline PCB & 1 & PC & 1 \\
\hline H & 1 & HC & 2 \\
\hline HPCB & 1 & PB & 1 \\
\hline HPCT & 1 & C & 1 \\
\hline HPC & 1 & HPBI & T \\
\hline PTB & 1 & B & 1 \\
\hline
\end{tabular}

H: Hardo; P: Pomona; C: Canicola; T: Tarassovi; B: Bratislavae; I: Icterohaemorrahagiae.

Previous studies have been conducted in Colombia on Human Leptospirosis, one of them in Sucre (northern state of Colombia) wherein $24.4 \%$ of rural workers were positive for ELISA test. This prevalence is almost twice that of our study which might be explained by differences in the type of population surveyed. Rios et al. referred lower prevalence in rural workers with activities that do not involve animal contact or workers who use barriers during animal contact. This finding is consistent with our results because veterinary students are more susceptible to infection during their training [11].

A seroprevalence of $17 \%$ was found in veterinarians and veterinary students by using ELISA IgM test in a study by Gongora et al. In the same report, some risk factors such as having contact with a dog or rodents were strongly associated to Leptospira antibodies, and positives from $4 \%$ to $61 \%$ in different human populations were described [12]. In contrast, the prevalence in our study is 2.5 times lower; a potential explanation for this is that Gongora study included only students from the last year of veterinary medicine while we surveyed students of all years.

Sixty nine patients with symptoms consistent with Leptospirosis were confirmed by MAT in a two-year study (20052006) conducted in Quindío (Central state of Colombia). The most frequent symp- 
toms were fever, muscular pain, cephalea, and jaundice [9]. Our work showed similar results except for jaundice.

Echeverri et al. evaluated 14 hospitalized patients with suggestive symptoms of Leptospirosis; 100\% were positive for IgM ELISA test, the major symptoms being fever $(100 \%)$ and jaundice $(64.3 \%)$ [6]. In our work, up to $60 \%$ of people surveyed developed symptoms of Leptospirosis yet just $25.1 \%$ had fever and 3.8\% experienced jaundice.

Seroprevalence by MAT in workers from Colombian animal sacrifice centers showed that $42 \%$ were positive for Hardjo, 38.9\% for Bratislava, $8.33 \%$ for Icterohaemorrhagiae, 5.6\% for Canicola, and $2.8 \%$ for Pomona [7]. We found similar results for Hardjo (41.2\%) although, in contrast, we found high seroprevalence of other serovars. This discrepancy might be explained by wide animal contact of veterinary students. In the same study, the most common symptoms were conjunctivitis $(90 \%)$, cephalea (52\%) and jaundice $(96.3 \%)$, in contrast to our findings of cephalea $(59.6 \%)$, fever $(25.1 \%)$, joint pain $(20.4 \%)$ and jaundice $(3.8 \%)$; it also might be due to other infection with similar symptoms to those of Leptospirosis. We reported that students had contact with animal species such as dogs, cattle, horses, rodents, pigs, poultry, sheep and goats. This finding is con- sistent with other studies where animal contact was higher than $70 \%$ with rodents, cattle, horses and dogs $[7,9,12]$.

In our study, all seropositive subjects reported having had any contact with animals or secretions, and $90 \%$ of 455 subjects had contact with animals during their school training.

Regarding animal Leptospirosis, some studies have shown that several Leptospira serovars are present in animals. Rodríguez et al. reported almost half of stray dogs as infected by Icterohaemorrhagiae serovar (55.6\%), followed by Hardjo (54.3\%), Gryppotyphosa (45.7\%), and Canicola serovar (38.3\%) [13]. Likewise, one study of swine Leptospirosis seroprevalence found $43 \%$ of prevalence by MAT, where Pomona was the major Leptospira serovar (34\%) [14].

A study in a Grocery Marketplace in Medellín, Colombia, found 25\% of rodents tested positive for MAT; this finding is important if we consider that infection is unusual in the urban context [15]. We found that $17.5 \%$ of students reported rodent contact. As Agudelo remarks, rodents and others animals in cities could be creating a new environment for Leptospira transmission and thus a new worrisome scenario for Public Health.

Results from this and other serological studies in humans and animals in 
our country suggest that ELISA test can be used in screening populations at risk, and that MAT is suitable for confirming the infection. Finally, they stand out the importance of using protective barriers by all populations who have regular animal contact including veterinary students [6].

\section{Acknowledgments}

We thank the participating students of the School of Veterinary Medicine, Universidad de La Salle, Bogota, Colombia; to Dr. Alexandra Rojas, for reviewing the manuscript, and Pilar Pérez, for laboratory support. Grant funding for laboratory supplies came from a Research Fund of Universidad Militar Nueva Granada, Bogota, Colombia (MED 650 and 787). Finally, we thank Dr. Nélida Forero Cubides, for her helpful review of the English manuscript.

Ethical approval: Ethical approval was obtained from the Universidad de La Salle and Universidad Militar, Bogota, Colombia. All subjects in the study signed the informed consent.

Conflict of interest: None of the researchers have conflict of interest. This work was presented in poster session 22.089 at International Meeting on Emerging Diseases and Surveillance IMED 2013, Viena, Austria, February $15-18^{\text {th }} 2013$.

\section{References}

1. Bharti A, Nally J, Ricaldi J, et al. Leptospirosis: a zoonotic disease of global importance. Lancet Infect Dis. 2003; 3: 757 -71. doi:10.1016/S1473-3099(03) 00830-2.

2. Levett P. Leptospirosis: A forgotten zoonosis? Clin Applied Immunol Rev. 2004; 4:435-48. doi:10.1016/j.cair.2004. 08.001.

3. Dutta TK, Christopher M. Leptospirosis - An Overview. J Assoc Physic India [internet]. 2005;53:545-551. Available from: http://www.japi.org/june2005/R-545.pdf.

4. Hartskeerl RA, Collares M, Ellis WA. Emergence, control and re-emerging leptospirosis: dynamics of infection in the changing world. Clin Microbiol Infect. 2011;17(4):494-501. doi: 10.1111/j.14690691.2011.03474.x.

5. Adler B, De la Peña A. Leptospira and Leptospirosis. Vet Microbiol. 2010; 140: 287-96. doi: 10.1016/j.vetmic. 2009. 03. 012.

6. Echeverri LM, Atehortua S, Ospina S. Leptospirosis con inmunoglobulina $\mathrm{M}$ positiva en pacientes hospitalizados en una institución de tercer nivel de Medellín, Colombia, en 2009. Infectio. 2011; 15(2):118-23.

7. Pedraza AM, Salamanca EE, Ramírez RY, et al. Seroprevalencia de anticuerpos anti-Leptospira en trabajadores de plantas de sacrificio animal en Boyacá, Colombia. Infectio. 2012;16(1):31-6.

8. Subdirección de Vigilancia y Control en Salud Pública. Boletín Epidemiológico Semanal: situación de los eventos zoonóticos [internet]. 2013;25:9-10. Available from: http://www.ins.gov.co/ boletin-epidemiologico/Boletn\%20Epidemiolgico/2013\%20Boletin\%20epidemiologico $\% 20$ Semana $\% 2025$.pdf. 
9. Sánchez G, Gómez J, Quintero L, Castaño M. Características clínicas y epidemiológicas de la leptospirosis en el departamento del Quindío, 2005-2006. Infectio. 2008;12(2):325-31.

10. Susuki M, Ariyoshi K. Leptospira serovar as prognostic factor. Emerg Infect Dis [internet]. 2010;16(8):1333. Available from: http://wwwnc.cdc.gov/eid/article/16/8/10-0520.htm.

11. Rios R, Franco S, Mattar S, Urrea M, Tique V. Seroprevalencia de Leptospira sp., Rickettsia sp. y Erlichia sp. en trabajadores rurales del departamento de Sucre, Colombia. Infectio. 2008;12(2):318-23.

12. Góngora A, Parra J, Aponte L, Gómez L. Seroprevalencia de Leptospira spp. en grupos de población de Villavicencio, Colombia. Rev Salud Pública. 2008;10(2):269-78.

13. Rodríguez A, Ferro B, Varona M, Santafé M. Evidencia de exposición a Leptospira en perros callejeros de Cali. Biomédica [internet]. 2004;24(3):291-5. Available from: http://www.revistabiomedica.org/index.php/biomedica/article/view/1275.
14. Almenteros C, Arrieta G, Mattar S, et al. Seroprevalencia de leptospirosis porcina en el departamento de Córdoba. Rev Col Cienc Pec [internet]. 2004;17(2):141-7. Available from: http://rccp.udea.edu.co/index.php/ojs/article/viewFile/163/161.

15. Agudelo $\mathrm{P}$, Londoño A, Quiroz V, et al. Prevalence of Leptospira spp. In urban rodents from groceries trade center of Medellín, Colombia. Am J Trop Med Hyg [internet] 2009;81(5):906-10. doi: 10.4269/ ajtmh.2009.09-0195.

\section{Correspondence}

Iván Alberto Méndez R.

Facultad de Medicina

Universidad Militar Nueva Granada

Tr. 5 \# 49-00

Bogotá, Colombia

ivan.mendez@unimilitar.edu.co 